\title{
10. DOWNHOLE LOGGING AT DEEP SEA DRILLING PROJECT SITES 501, 504, AND 505, NEAR THE COSTA RICA RIFT ${ }^{1}$
}

\author{
J. R. Cann, Department of Geology, The University, Newcastle upon Tyne, NE1 7RU, United Kingdom \\ and \\ R. P. Von Herzen, Woods Hole Oceanographic Institution, Woods Hole, Massachusetts
}

\begin{abstract}
Successful logs were taken in four holes in the area of the Costa Rica Rift during DSDP Legs 69 and 70. The logs clearly show the chert layers in limestone at the base of the sedimentary section of Holes 501 and 504A and the alternation of the massive flow units and pillow basalts in the basement section of Holes 501 and 504B. Nearly continuous neutron and resistivity logs of the 562 meters of basement section of Hole 504B show that the porosity of the basalt decreases gradually from about $13 \%$ near the sediment/basalt interface to about $6 \% 250$ meters into the basement. Below that depth porosity is approximately constant. A comparison of the resistivity and neutron logs suggests that pores in regions of high porosity near the top of the basement are more connected than in similar regions deep in the hole. The caliper log for Hole 504B shows that the size of the hole is generally close to the size of the bit but has variations that are not clearly related to either porosity or permeability. The compensated density log, although it gives a good indication of the variation of porosity, is not a reliable indicator of the values of formation porosity in high porosity zones. The sonic log is noisy on a fine scale but gives an idea of large-scale structure that correlates well with the values of porosity derived from resistivity.
\end{abstract}

\section{INTRODUCTION}

During Legs 68 (501), 69, and 70 of the Deep Sea Drilling Project, logs were obtained in four holes drilled in two contrasting areas of the Costa Rica Rift to investigate both open and sealed circulation of heated ocean water within the ocean crust (Fig. 1).

In the area where circulation is believed to be open to the ocean, where heat flow is low, drilling the brittle, fractured, little altered basalt proved to be very difficult. It was only with great effort that in one hole (Hole 505B) we penetrated 40 meters into basement. We managed to $\log$ most of that basement section. We also logged a section of the overlying sediment, but the cold, unaltered sediment had washed out beyond caliper range during drilling, and the logs were not very satisfactory.

Drilling was much better in the high-heat-flow area, where hydrothermal circulation was believed to be sealed beneath a continuous blanket of sediments. Hole 501, the pilot hole for re-entry, penetrated 70 meters into basement beneath 250 meters of sediment that had been diagenetically altered to chert and limestone over its lowest 30 meters. Here the lower 120 meters of sediment and most of the basement was logged. We made a first attempt at re-entry only a few hundred meters from this site, at Hole 504A. The attempt failed when the casing bit broke up only a few meters into basement. We made one logging run, primarily to record temperature but also to acquire a gamma density record of the chert layers. The eventually successful re-entry hole, Hole 504B, was cased to basement and then drilled, first to $212 \mathrm{me}-$ ters of basement penetration on Leg 69 and eventually

\footnotetext{
${ }^{1}$ Cann, J. R., Langseth, M. G., Honnorez, J., Von Herzen, R. P., White, S. M., et al. Init. Repts. DSDP, 69: Washington (U.S. Govt. Printing Office)
}

to 562 meters of basement penetration on Leg 70 . Suites of logs were run in the basement section at the end of the drilling on both legs, with different rates of success on each leg. These logs provide the principal interest of the Costa Rica Rift drilling, if only because of their length, which allows a clear view of the extent of the fluctuations of the physical properties of the basement.

The logging tools used for the standard logging runs were part of a logging package that was provided under contract by Gearhart-Owen, Incorporated. GearhartOwen logging engineers operated the tools: Larry Axline sailed on Legs 68 and 69 and David Collart on Leg 70. The technical specifications for the logging tools are given in Table 1. The logging results were interpreted by using the appropriate charts in the Gearhart-Owen manual, supplemented where necessary by charts in the Schlumberger logging manual. The results of all logs except the temperature log are discussed here. The temperature logs are discussed by Becker et al. (this volume) in conjunction with the other temperature measurements. Two special tools that were not part of the GearhartOwen package were also run during the logging program. They are both discussed in other chapters of this volume, the downhole magnetometer by Ponomarev and Nekhoroshkov and the borehole televiewer by Anderson and Zoback.

Different suites of logs were run during five logging periods with varying degrees of success (Table 2). The sonic tool did not work at all effectively on Legs 68 and 69; it worked better, though still noisily, on Leg 70 . Conversely, the gamma density tool worked well on the earlier two legs but failed during the logging of the deep Hole 504B on Leg 70. Despite occasionally good operation during Legs 68 and 69, the natural gamma tool was ineffective because of the scarcity of radioactive elements in the section, and it gave particularly noisy read- 


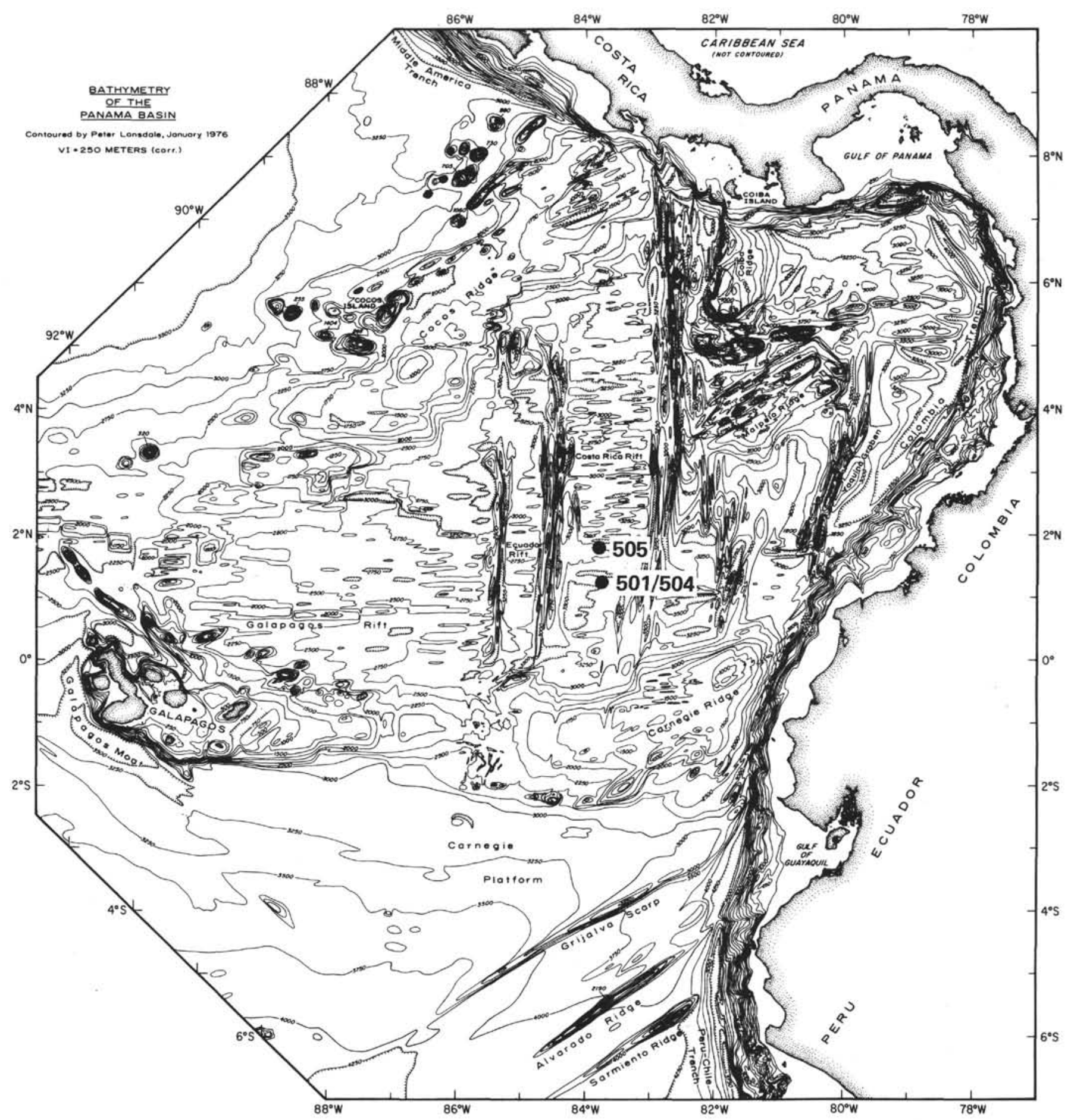

Figure 1. Location of Sites 501, 504, and 505 near the Costa Rica Rift. Sites 501 and 504 are in the high-heat-flow area, and Site 505 is in the lowheat-flow area (see text). After Lonsdale and Klitgord (1978). Contour interval $=250 \mathrm{~m}$.

ings during Leg 70, when it may not have been transmitting any meaningful signal. It was equally ineffective in combination with the neutron tool because of the activated radioactivity of the formation resulting from neutron bombardment. Both the neutron and the resistivity logs duplicated themselves nearly exactly from run to run, however, and they could be interpreted successfully in relation to one another. Both types of logs were run successfully in Holes 501, 505B, and both basement sections of Hole 504B.

\section{RESULTS}

The results from the different logs run in each hole are shown in Figures 2 to 6 . Where the same log was run more than once, the record shown is the best obtained. Some logging runs have been omitted, such as the sonic 
Table 1. Characteristics of the logging tools used.

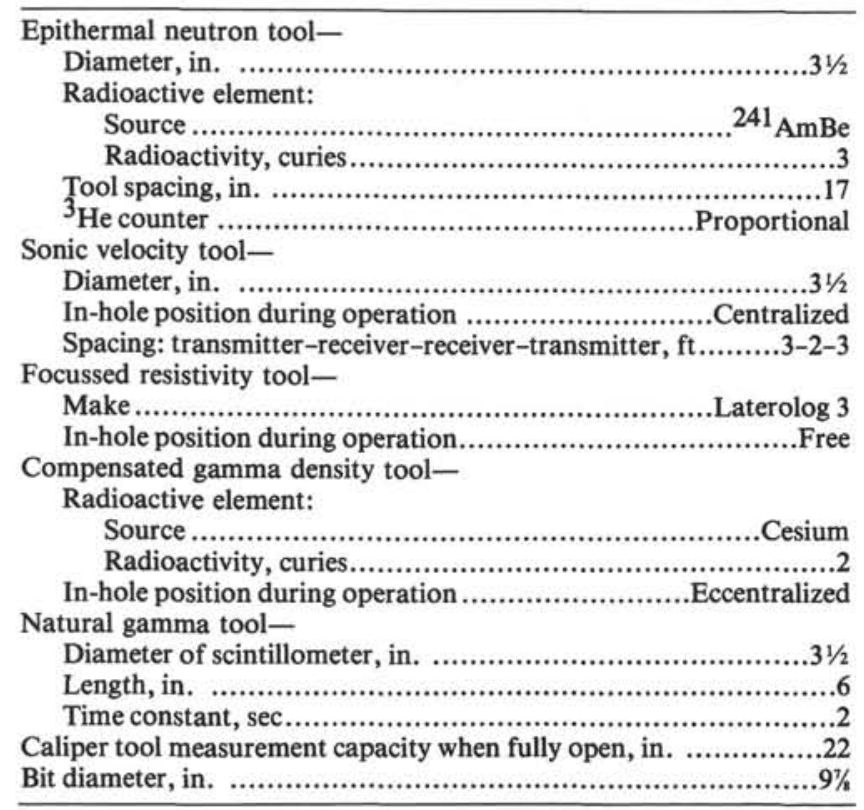

$\log$ for Hole 501, because the resulting data are clearly unusable. In the case of that log, for example, values were frequently reached that either fell below the velocity of sound in water or exceeded the velocity of sound in peridotite. Other records have been included despite their poor quality in case something can be extracted from them.

Most of the logs showed great reproducibility from run to run in the same hole. This was particularly true of the neutron, resistivity, and caliper logs. The excellence of their agreement can be seen by comparing Figures 4 and 5A, which cover the same section of Hole 504B but were run on different legs. The compensated gamma density results were broadly comparable from run to run but did not agree so closely, probably because the tool is run eccentralized and is incapable of penetrating very far into the formation. The natural gamma log results showed only fair reproducibility, partly as a consequence of the noisy signal on Leg 70 but also because of variable time constant and scale problems in other holes. The details of the best sonic log failed to match those of a second run of the same section, but when the values were averaged over intervals of 10 meters or more, meaningful data began to appear.

Qualitatively, the logs show some features particularly well. Near the base of the sedimentary section in Holes 501 and 504A (Figs. 2 and 3), the appearance of layers of chert is clearly visible. The borehole televiewer images show these layers to be sharply defined, horizontal, and highly reflective and to be separated by layers of lower reflectivity that are probably the softer limestones (Anderson and Zoback, this volume). From the compensated gamma density, neutron, and resistivity logs in Figure 2, the upper boundary of the chert-bearing unit at 3699 meters is in sharp contrast to the softer, uniform siliceous chalk above. The complexity of the chert-bearing unit shows up clearly in the spiky records that result from the 10 -cm-scale alternation of chert and limestone.
Table 2. Logging operations in the Costa Rica Rift.

\begin{tabular}{|c|c|c|c|c|}
\hline Leg & Hole & Date & Run & $\begin{array}{l}\text { Record } \\
\text { Quality }\end{array}$ \\
\hline \multirow[t]{11}{*}{68} & 501 & 12 to 13 July & $\begin{array}{l}\text { Sonic velocity } \\
\text { Natural gamma } \\
\text { Caliper }\end{array}$ & $\begin{array}{l}\text { Unusable } \\
\text { Excellent } \\
\text { Excellent }\end{array}$ \\
\hline & & 13 July & Compensated gamma density & Good \\
\hline & & & Natural gamma & Good \\
\hline & & & Caliper & Good \\
\hline & & 13 July & Borehole televiewer & Good \\
\hline & & 14 July & Downhole magnetometer & Good \\
\hline & & 14 July & Temperature & Excellent \\
\hline & & & Water sampler & Poor \\
\hline & & 15 July & Focussed resistivity & Excellent \\
\hline & & & Neutron porosity & Excellent \\
\hline & & & Natural gamma & Unusable \\
\hline \multirow[t]{4}{*}{69} & $504 \mathrm{~A}$ & 26 October & Compensated gamma density & Good \\
\hline & & & Natural gamma & Good \\
\hline & & & Caliper & Failed \\
\hline & & & Temperature & Excellent \\
\hline \multirow[t]{13}{*}{69} & $504 \mathrm{~B}^{\mathrm{a}}$ & 22 October & Compensated gamma density & Good \\
\hline & & & Natural gamma & Good \\
\hline & & & Caliper & Good \\
\hline & & & Temperature & Excellent \\
\hline & & 22 October & Focussed resistivity & Excellent \\
\hline & & & Neutron porosity & Excellent \\
\hline & & & Natural gamma & Unusable \\
\hline & & 23 October & Downhole magnetometer & Failed \\
\hline & & 23 October & Borehole televiewer & Good \\
\hline & & 24 October & Downhole magnetometer & Good \\
\hline & & 24 October & Temperature & Excellent \\
\hline & & & Self potential & Failed \\
\hline & & & Water sampler & Excellent \\
\hline \multirow[t]{17}{*}{70} & 504B & 13 December & Sonic velocity & Moderate \\
\hline & & & Natural gamma & Poor \\
\hline & & & Caliper & Excellent \\
\hline & & & Temperature & Excellent \\
\hline & & & Water sampler & Excellent \\
\hline & & 14 December & Compensated gamma density & Failed \\
\hline & & & Natural gamma & Poor \\
\hline & & & Caliper & Good \\
\hline & & & Temperature & Excellent \\
\hline & & 15 to 16 December & Focussed resistivity & Failed \\
\hline & & & Neutron porosity & Poor \\
\hline & & & Natural gamma & Poor \\
\hline & & 16 December & Temperature & Excellent \\
\hline & & & Water sampler & Excellent \\
\hline & & 16 December & Focussed resistivity & Excellent \\
\hline & & & Neutron porosity & Excellent \\
\hline & & & Natural gamma & Unusable \\
\hline \multirow[t]{10}{*}{69} & $505 \mathrm{~B}$ & 5 October & Compensated gamma density & Good \\
\hline & & & Caliper & Good \\
\hline & & & Natural gamma & Good \\
\hline & & & Temperature & Good \\
\hline & & 5 to 6 October & Downhole magnetometer & Good \\
\hline & & 6 October & Focussed resistivity & Good \\
\hline & & & Neutron porosity & Good \\
\hline & & & Natural gamma & Poor \\
\hline & & 7 October & Temperature & Poor \\
\hline & & & Water sampler & Poor \\
\hline
\end{tabular}

${ }^{a}$ All of the runs in Hole 504B during Leg 69 logged only the upper $200 \mathrm{~m}$ of the $562 \mathrm{~m}$ finally drilled in the basement section.

The same structure can be seen in the compensated gamma density log of Hole 504A (Fig. 3). The logs also give records for the chalk section above the cherts, but because of the large hole size their accuracy is open to question. However, the values of compensated gamma density are closely comparable to measurements made on samples taken from the hydraulic piston core of nearby Hole 504 (Wilkens and Langseth, this volume).

Immediately above the basalt in Holes 501, 504A, and possibly 504B (Figs. 2, 3, and 4) there is a high-porosity unit with a high natural gamma count. The large peak in the downhole magnetometer record at this level in Hole 501 (Fig. 2 and Ponomarev and Nekhoroshkov, 


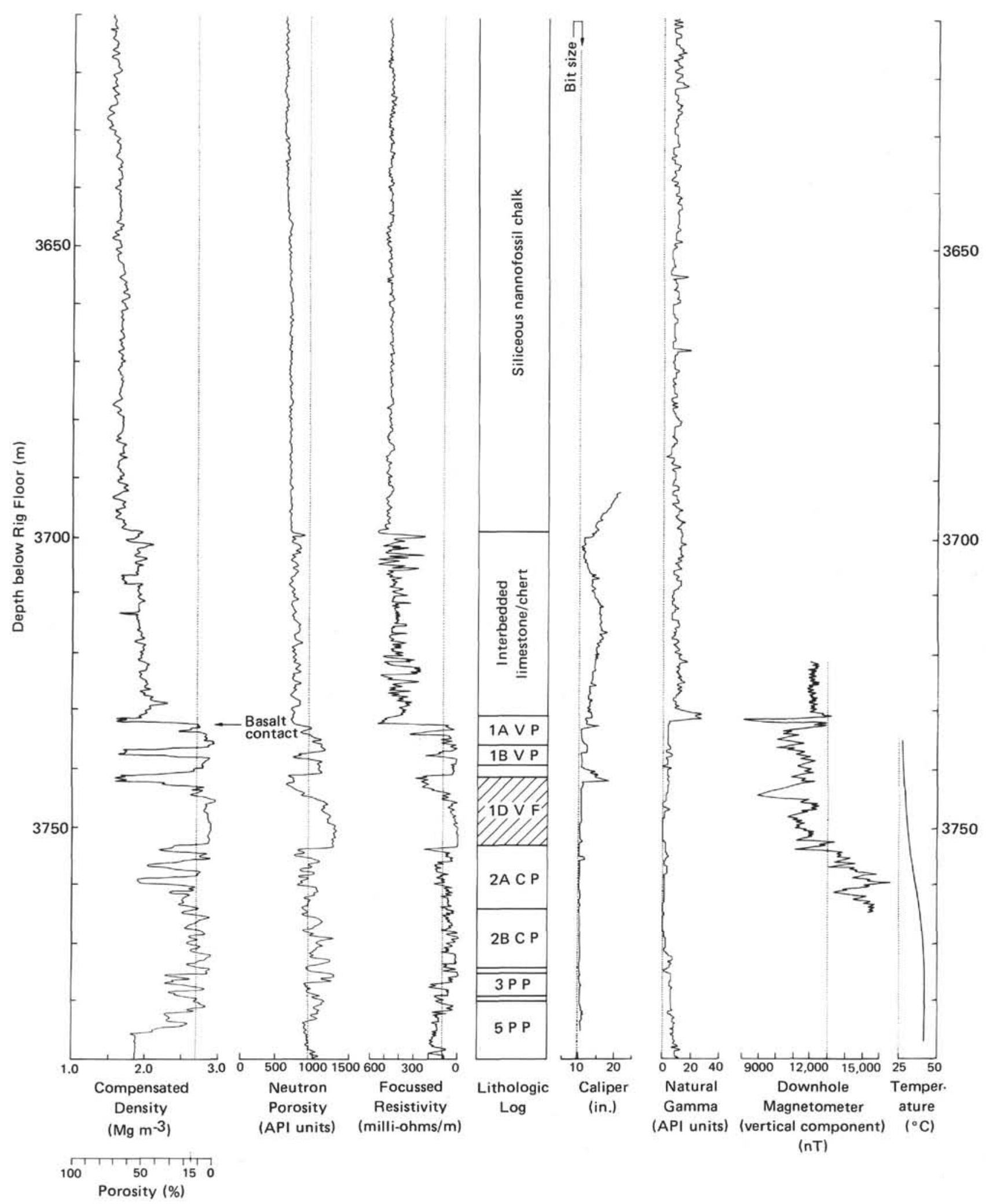

Figure 2. Logs run in Hole 501. Depths are meters below rig floor. The seafloor was at $3467 \mathrm{~m}$, and the top of the basalt section was at $3731 \mathrm{~m}$. Dotted lines are for reference. The caliper was fully extended at all depths shallower than $3693 \mathrm{~m}$. The electrical conductivity log was derived by computation from the focussed resistivity measurements. Cross-hatched block in lithologic log shows massive flow unit. In lithologic log, first letter stands for basalt type based on phenocryst assemblage, as follows: $\mathrm{C}$, chromite bearing; $\mathrm{P}$, clinopyroxene bearing; V, variably bearing. Second letter refers to basalt form, as follows: P, pillow basalts; F, flows. 


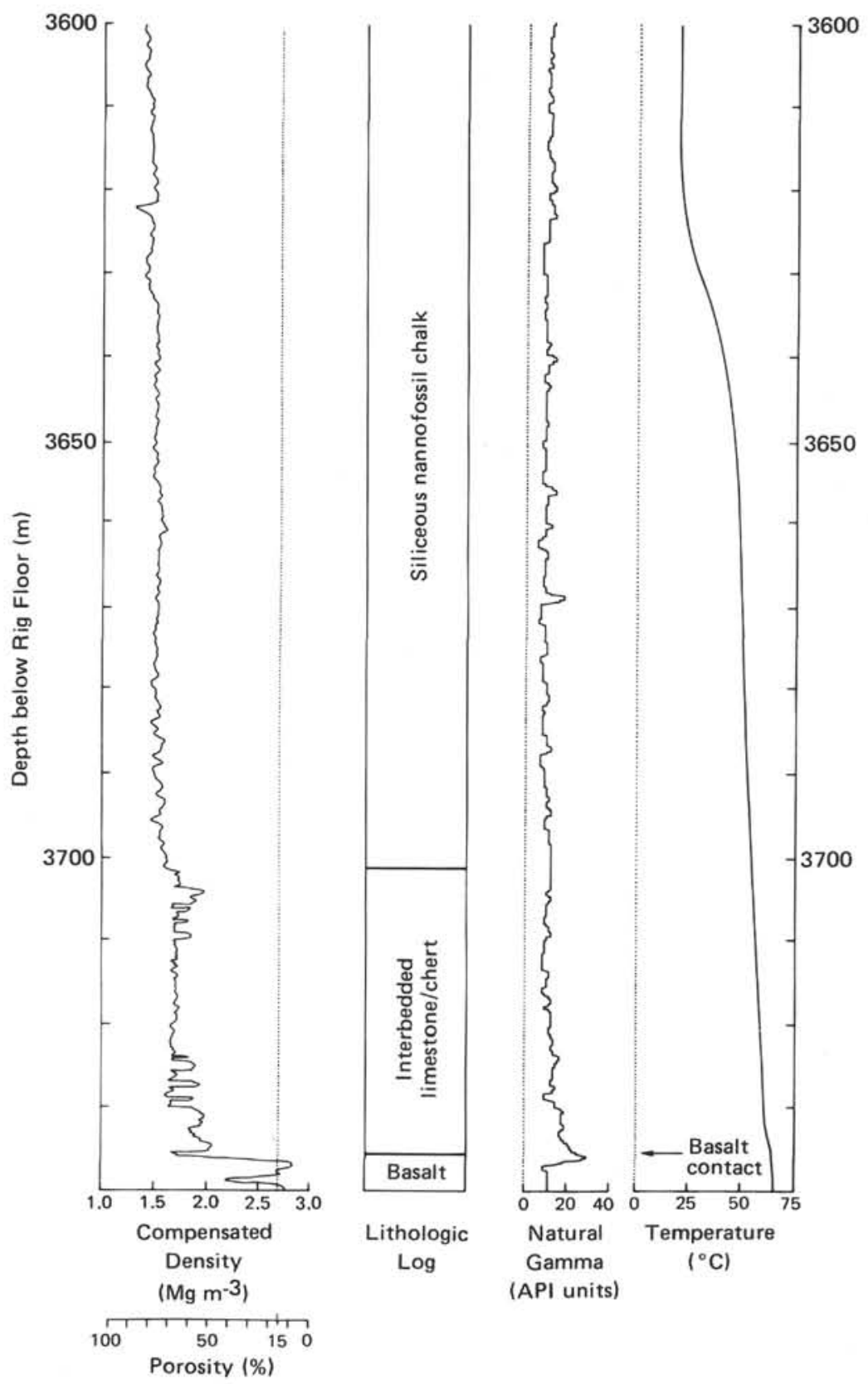

Figure 3. Logs run in Hole 504A. Depths are meters below rig floor. The seafloor was at $3468 \mathrm{~m}$, and the top of the basalt section was at $3732 \mathrm{~m}$. Dotted lines are for reference.

this volume) is probably associated not with anomalous magnetization at this horizon, however, but with the magnetic edge effect between nonmagnetic sediment and magnetic basalt. The nature of this horizon is not certain, since no material was recovered from it; the immediately overlying hard chert required drilling with full circulation. It is probably a hydrothermal sedimentary layer that is forming just above the basalt near the ridgecrest.

Within the basement section, the most striking features are the massive flow units, which are several meters thick. The rate of recovery for these intervals was high, and the core was sometimes recovered as continuous sticks. The uniformly coarse-grained nature of the basalt in these intervals leaves no doubt that they are single outpourings or injections of basalt, although it is not clear whether they are truly massive flow units or sills. Within the massive flow units, all the porosityrelated logs show low, uniform porosity. The borehole televiewer records show the uppermost massive unit in Hole 501 to be extremely uniform, with sparse random cracking (Anderson and Zoback, this volume). The logs are particularly useful in defining the upper and lower boundaries of the units, which are not always evident from the cores recovered.

Between the massive units the porosity-related logs show an oscillation between high and low porosity with a wavelength of 1 to 3 meters. It never settles on a con- 


\section{J. R. CANN, R. P. VON HERZEN}

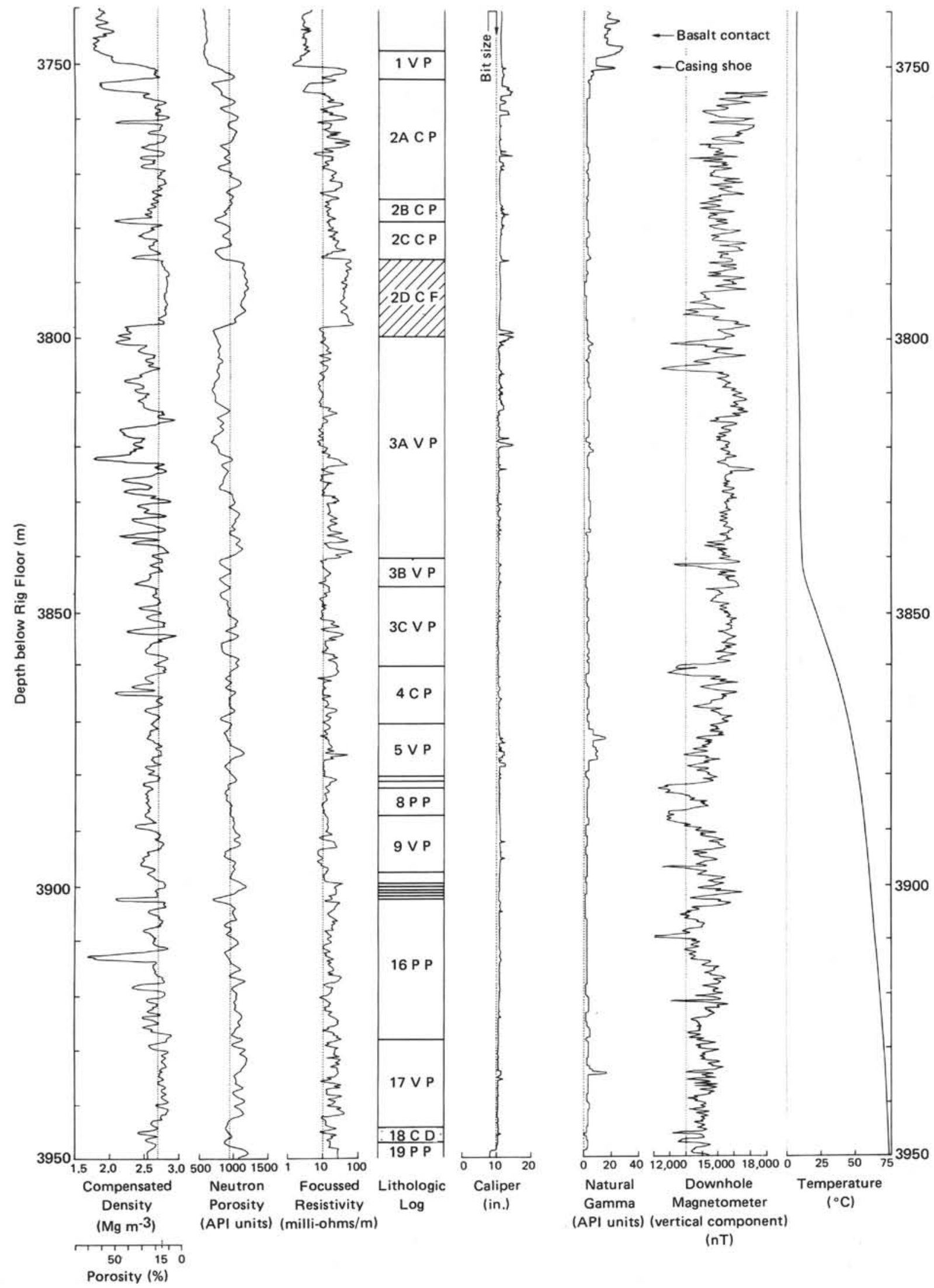

Figure 4. Logs run in Hole 504B on Leg 69, covering the upper part of the basement section. Depths are meters below rig floor. The seafloor was at $3474 \mathrm{~m}$, and the top of the basalt section was at $3748 \mathrm{~m}$. The hole was cased from the mudline to $7 \mathrm{~m}$ into the basalt. Dotted lines are for reference. Units in lithologic log are identified as in Figure 2, with D standing for depth. 


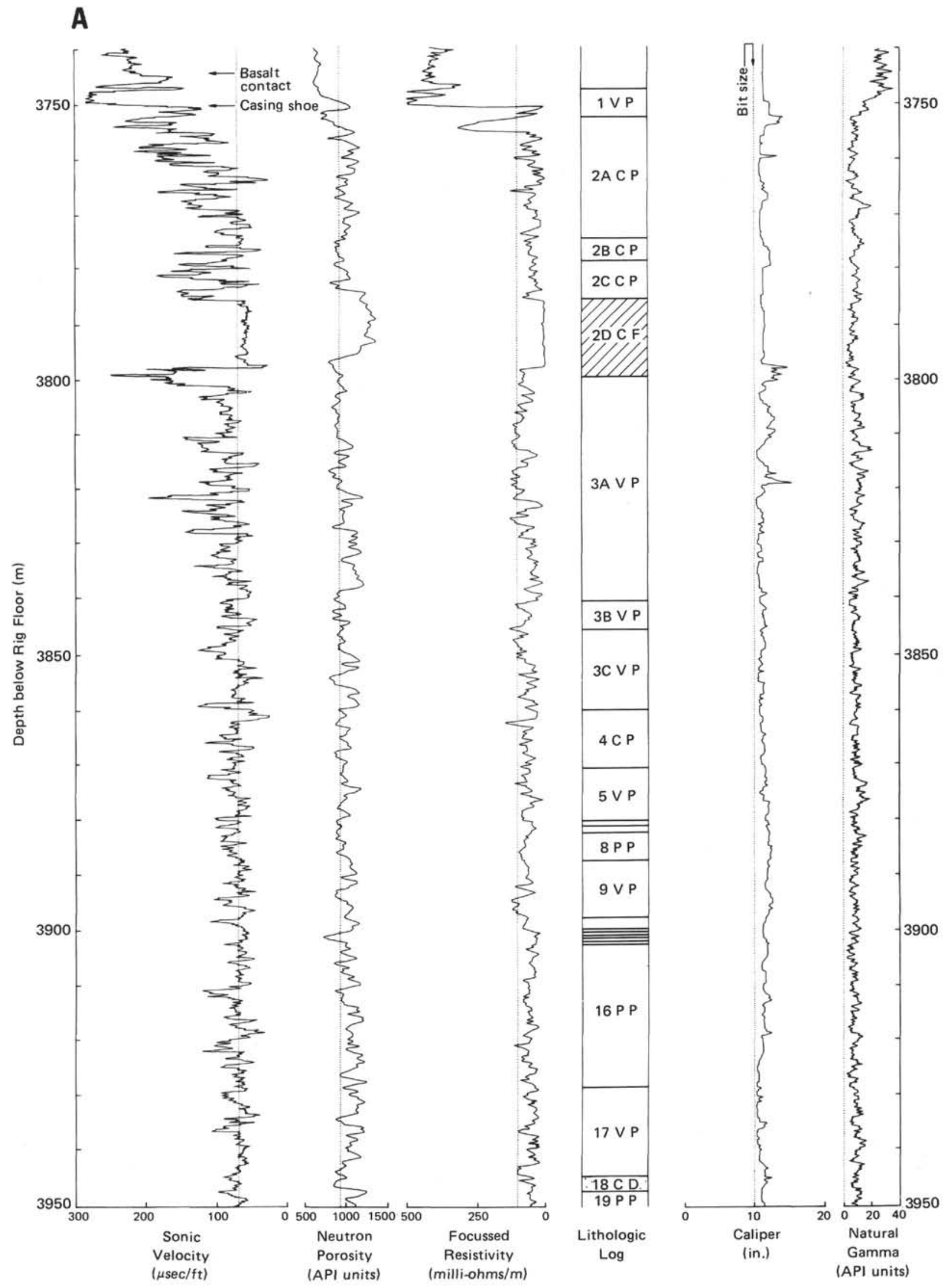

Figure 5. Logs run in Hole 504B on Leg 70, covering the whole of the basement section. Depths are as for Figure 3. The electrical conductivity log was derived by computation from the focussed resistivity measurements. Dotted lines are for reference. Units in lithologic log are identified as in Figure 2. (A) 3750-3950 m, (B) 3950-4150 m, (C) 4150-4300 m. 

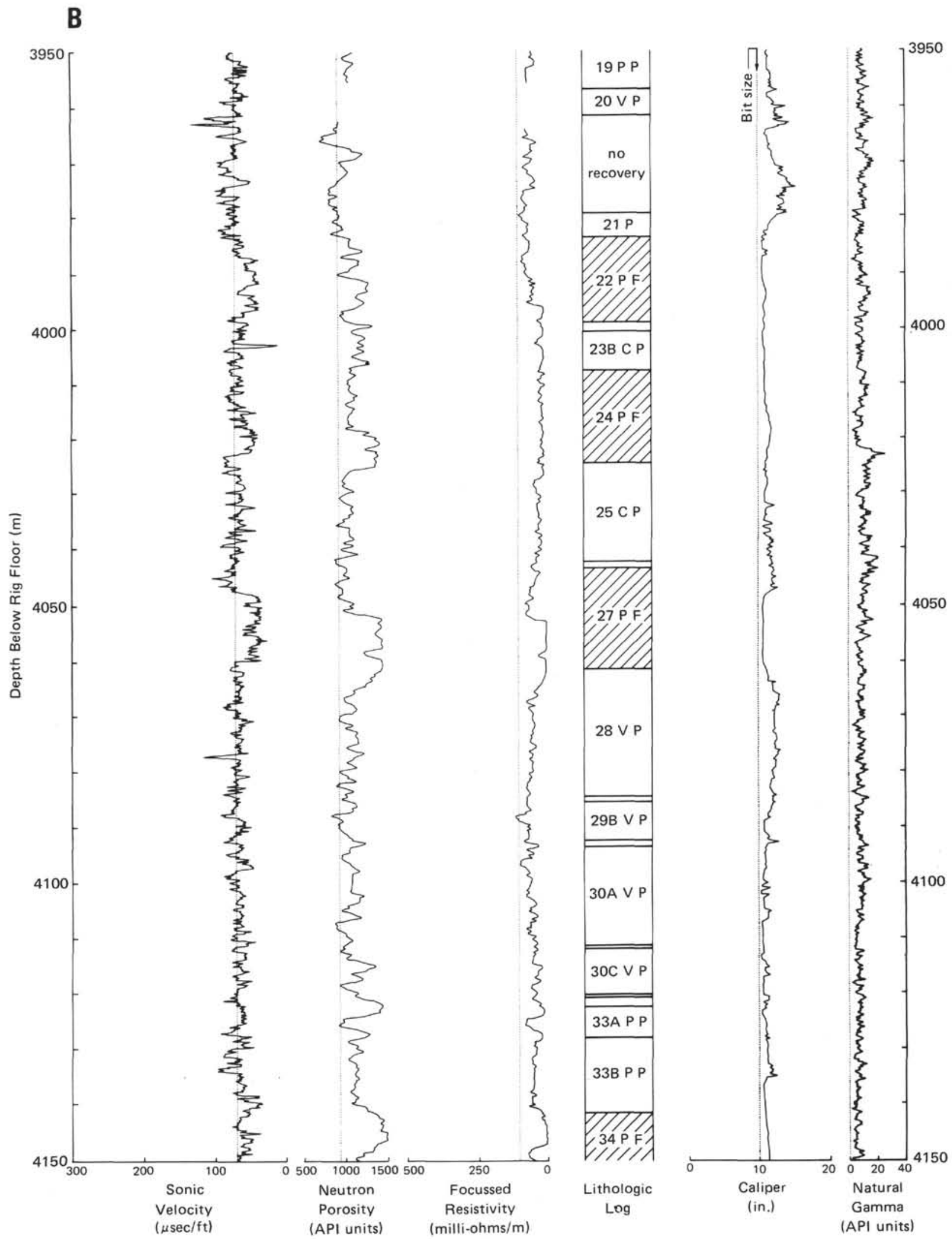

Figure 5. (Continued). 

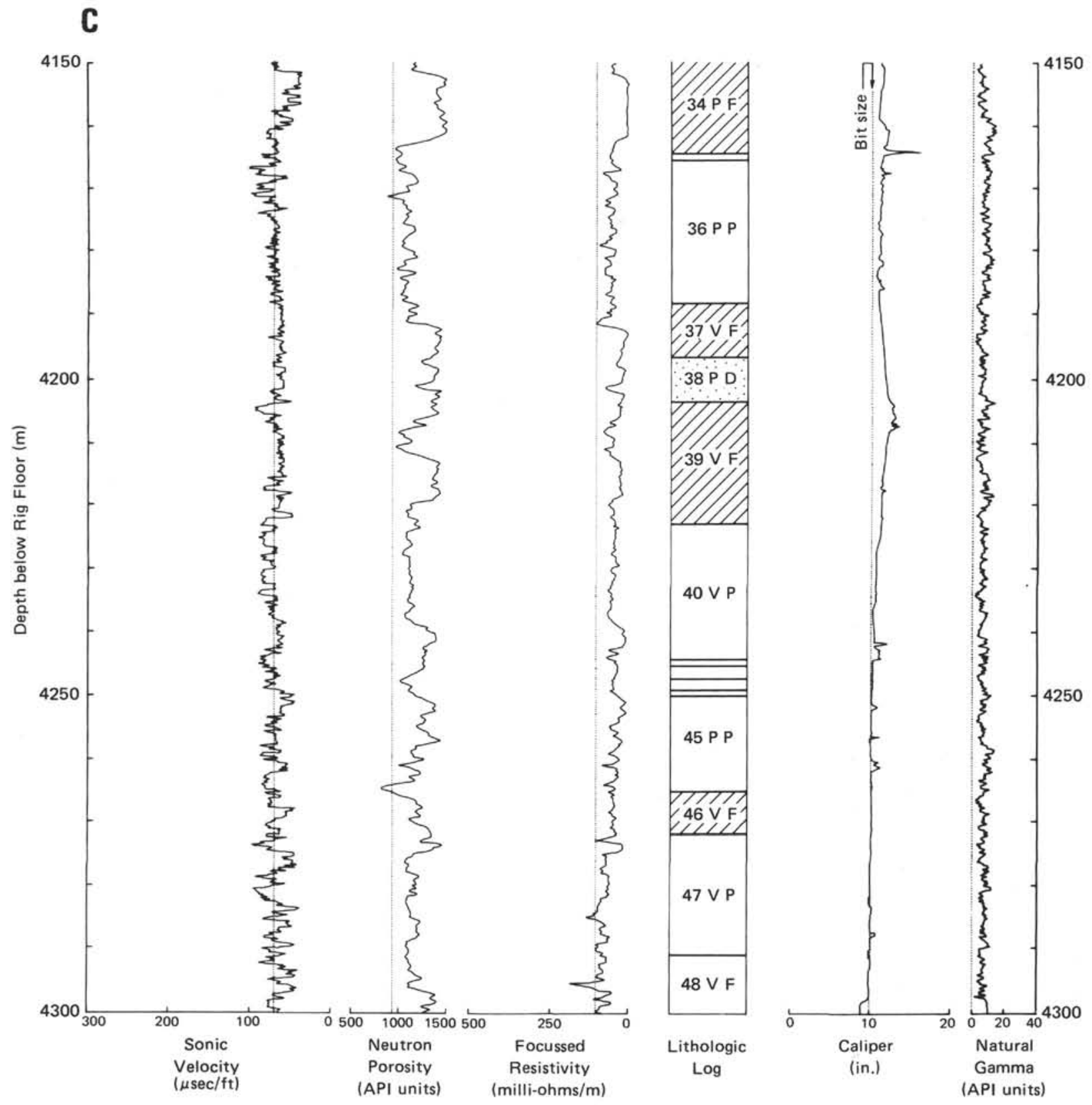

Figure 5. (Continued).

stant porosity or distinguishes units on a larger scale. Recovered basalt and borehole televiewer images of the upper part of the hole (Anderson and Zoback, this volume) show that these intervals are mostly pillow basalt, with some thin flows. Sections of logs can sometimes be very precisely matched with one another, with individual highs and lows clearly correlated. In such intervals corresponding points can be readily identified. In other intervals the correlation is not so good, and the reason is not always clear. Ship's heave or the tools' snagging on the walls of the hole can degrade a record that would otherwise match. On the other hand, the two logs record different variables, and they might give different values even under ideal conditions. For convenience and con- sistency, the first explanation was assumed to be correct, although it was fully understood that both factors were likely to have operated.

It is not easy to identify highly fractured intervals of the section from the porosity-related logs. The intensity of fracturing, although very important to the permeability of the formation, is not necessarily directly related to porosity. The intensity of fracturing might be easier to infer from the caliper $\log$, because the sides of a hole often break away along closely spaced fractures. Figure 7 is a condensed caliper log for Hole 504B, which was sampled at 1-meter intervals. Some parts of the hole are 2 in. or so larger than bit size, and the enlargements are often accompanied by irregularities in the walls. One 


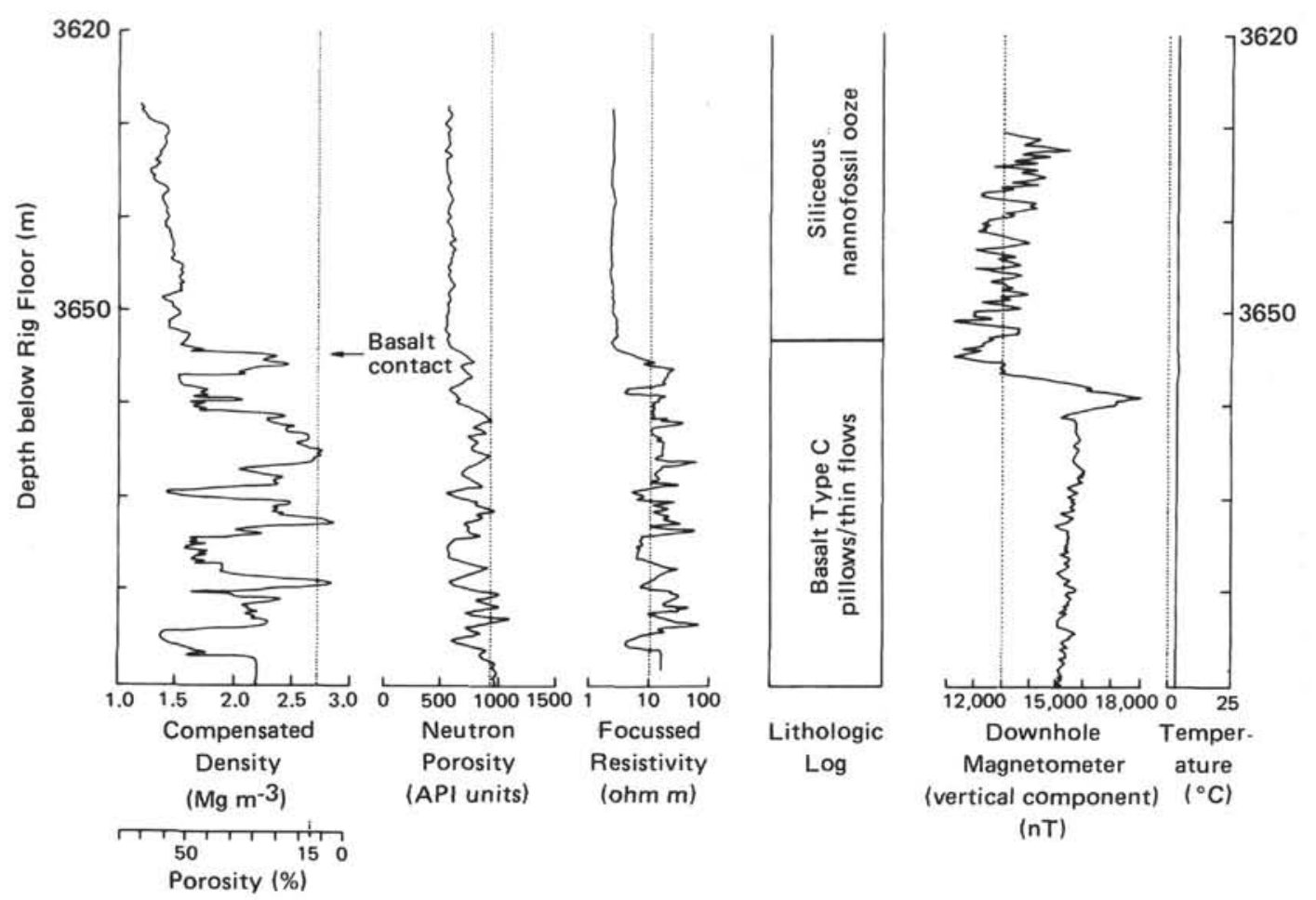

Figure 6. Logs run in Hole 505B on Leg 69, covering the basalt sediments and the short basement section. Depths are in meters below rig floor. The seafloor was at $3517 \mathrm{~m}$, and the top of the basalt section was at $3653 \mathrm{~m}$.

would expect such intervals to be zones of high permeability, but this does not seem to be the case. The thermal history of the hole (Becker et al., this volume) suggests very strongly that there is a zone of high permeability at sub-bottom depths of 90 to 100 meters (about $3850 \mathrm{~m}$ below the rig floor) through which water is flowing into the surrounding rock. There is no particular anomaly in the caliper log at this depth. Conversely, zones that are particularly anomalous in the caliper log, such as those at 3800 and 3975 meters below the rig floor ( 50 and 225 $\mathrm{m}$ into the basement) fail to show any indication of outflowing water in the thermal log.

One feature of the caliper log that is worthy of note is the apparent periodicity of the variations in hole diameter with increasing depth. The periodicity is apparently unrelated to the porosity logs (see material following) or to the presence of massive flow units in the section (shaded bars in Fig. 7). Between five and six cycles in hole diameter occur between 3800 and 4200 meters, which gives a wavelength of 70 to 80 meters. Such periodicity is similar to that reported by Francis (1982), although it is of somewhat shorter wavelength. Francis attributes the periodicity to the oscillation of the drill string in the hole, which in turn is related to the changes in the dynamics of the drill string as the length of the string increases. He believes that the hole is widened by being reamed out by the upper edge of the bottom hole assembly. The operation of such a factor is very possible here, especially if the caliper of the lower part of the hole is compared with the profile given by Francis (1982, fig. 5) of the lower part of drill string at an appropriate horizontal exaggeration.

\section{POROSITY-RELATED LOGS IN HOLE 504B}

We analyzed the porosity-related logs of Hole 504B further to improve our understanding of the porosity of the section. Corresponding pairs of points were read from the Leg 70 neutron and resistivity logs and from the Leg 69 compensated gamma density log, although the compensated gamma density log covered only the top 200 meters of the basement section. To identify corresponding points, parts of the curves that were similar in shape were chosen where possible. An overall shift of 8 meters in the Leg 70 logs relative to the Leg 69 logs proved to be necessary to match the massive units that appeared in both legs. This adjustment is incorporated throughout the analysis discussed in this chapter.

The neutron density logs give values on the API scale that were converted to porosity by calibration curves. No curves were available for the precise combination of tool spacing and hole diameter used here, so a curve was interpolated between those given for different combinations of spacing and hole diameter by Schlumberger (1974) and Gearhart-Owen (1976). Individual values of porosity are plotted as $\phi N$ in Figure 8A. The effects of variations in temperature and hole diameter were assumed to be minor in comparison to the inaccuracies otherwise present in the analysis. This can be confirmed for low porosities by comparing the neutron porosities for the massive flow units at different depths in the hole. For all of the massive flow units, calculated porosity is 3 to $6 \%$, with little variation with either depth (and hence temperature) or hole diameter (see Fig. 7 and discussion thereof). The massive units are physically 


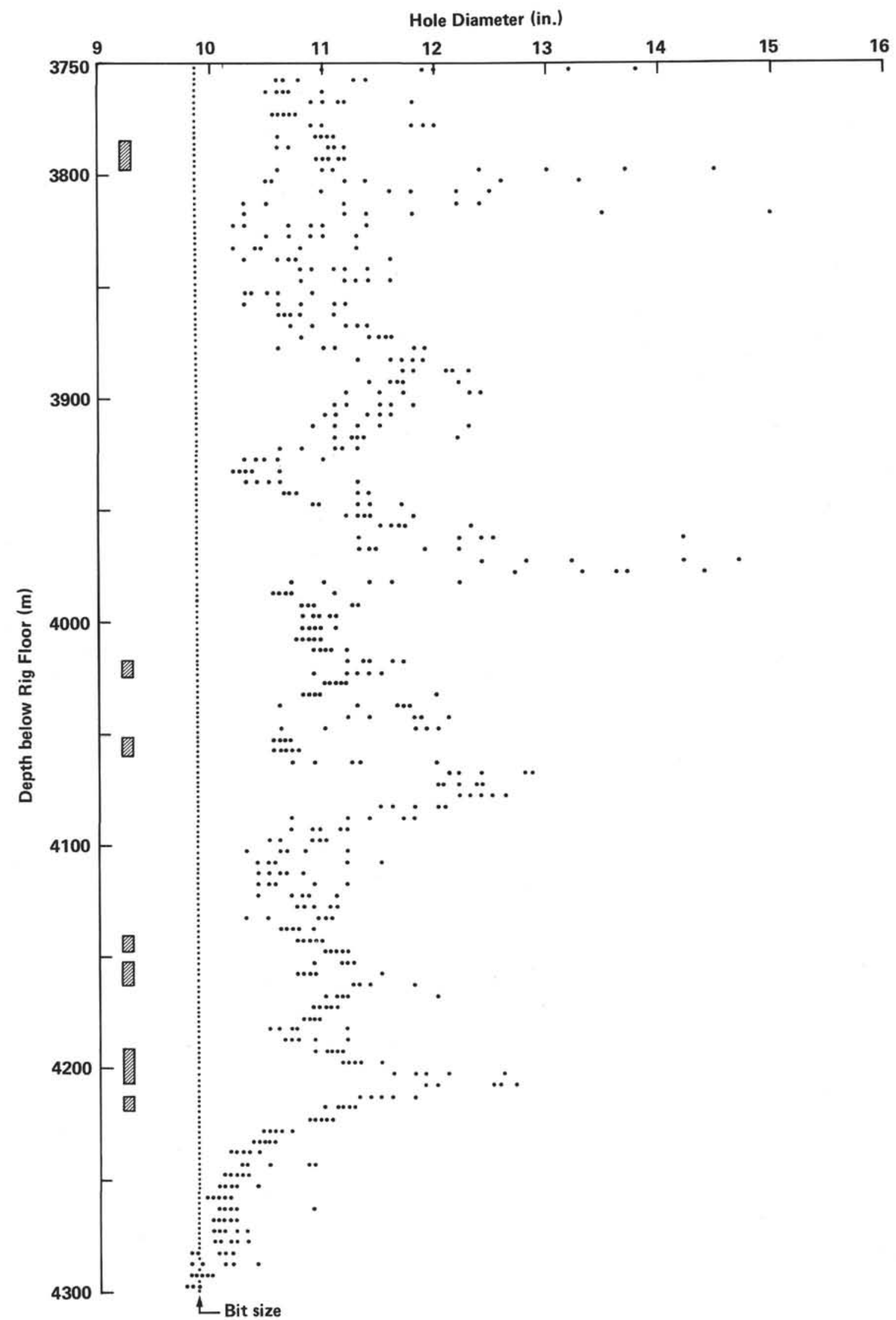

Figure 7. Caliper log for the Hole 504B basement section (Leg 70). Points are sampled from the log at 1-m intervals and plotted in groups of five at 5-m intervals. Bars at left show massive flow units. 


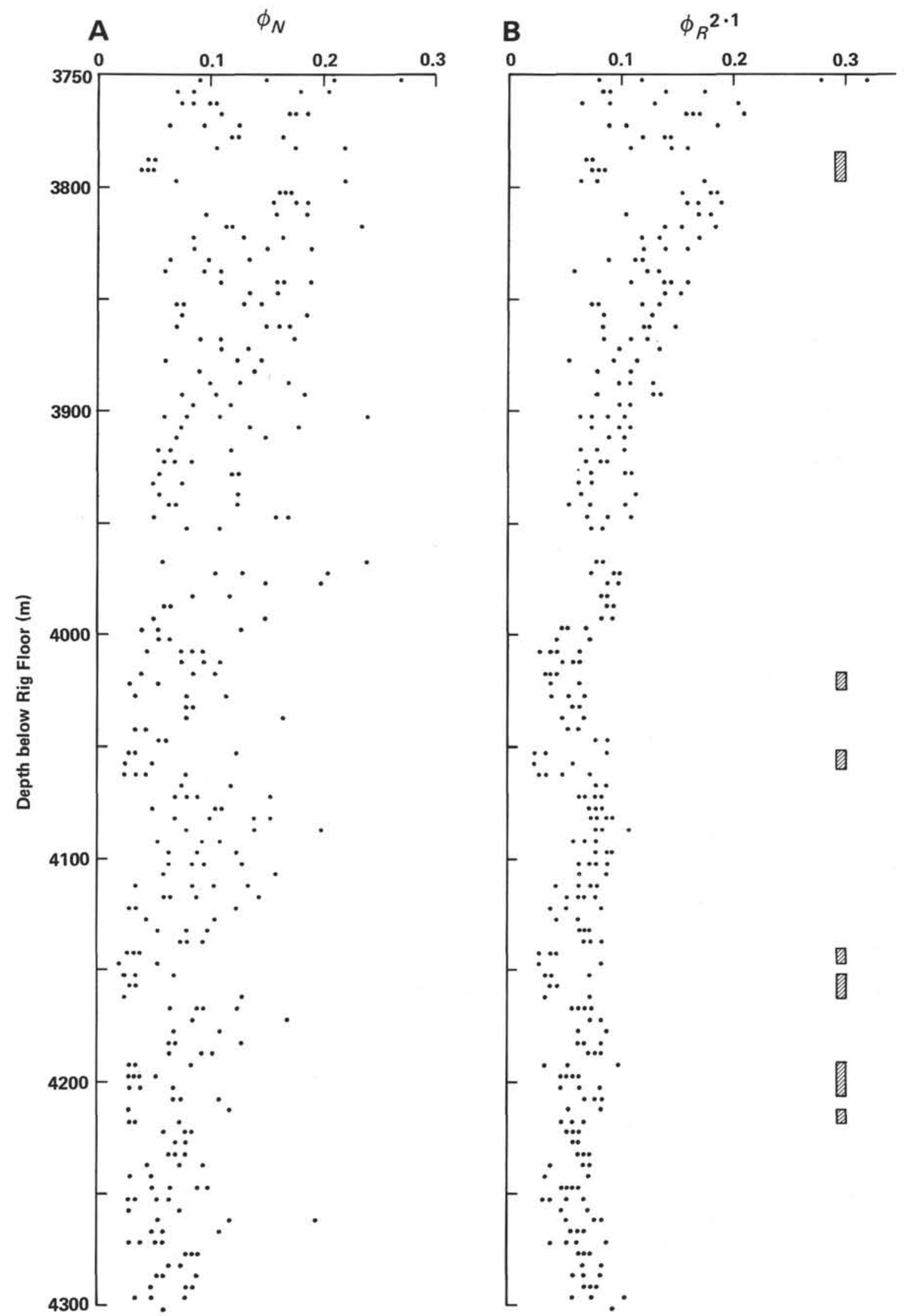

Figure 8. Porosity values calculated from (A) neutron $\log$ and (B) focussed resistivity $\log$ for Hole 504B basement section. Points are sampled from correlated peaks and troughs, and thus correspond from one leg to the other. Porosity is expressed as a fraction. Bars show massive flow units. 
very uniform, so such uniformity would be expected. For higher porosities, a comparison of the different curves suggests that the effect of variations in hole diameter should be much less marked than the effects of porosity variation, and this was assumed to be the case here.

In relating resistivity to porosity the empirically based Archie's Law was used:

$$
\phi^{q}=\frac{R_{w}}{R_{f}}
$$

where $\phi$ is porosity, $\mathrm{q}$ is an empirical exponent that depends on the connectedness of the cracks, $R_{w}$ is the resistivity of the seawater that fills the pores, and $R_{f}$ is the observed resistivity of the formation (Archie, 1942). Since the resistivity of seawater depends critically on temperature, a temperature correction must be applied in entering $R_{w}$. This correction was determined by using a temperature log that was run on the same day as the resistivity log (16 Dec.). Analyses of water samples (Mottl et al., this volume) indicated that the water in the hole and in the formation had the same salinity as seawater, so it was possible to compile curves showing the change in $R_{w}$ with increasing depth in the hole by using the resistivity-temperature-salinity curves in the Gearhart-Owen data handbook (1976). See also Schlumberger (1979, chart Gen. 9).

The next step in finding porosity requires some information about $\mathrm{q}$, which must be assigned a constant value (even though the connectedness of cracks is likely to change throughout the section) to make it possible to derive semi-independent information about porosity from resistivity. Often assumed to be 2 , q was derived for this study as follows. Archie's equation was solved for $\mathrm{q}$ for each point by using neutron porosity as a measure of $\phi$, the observed value of $R_{f}$, and the value of $R_{w}$ appropriate for the temperature at the appropriate depth. The median value of all values of q calculated in this way was 2.1 , with a spread from the twentieth percentile to the eightieth percentile of 1.9 to 2.4 . This value was then used throughout the hole to solve Archie's equation with the observed values of $R_{f}$ and appropriate values of $R_{w}$ as described previously to give a semi-independent set of porosity values. The values of porosity calculated from resistivity in this way are shown as $\phi_{R}$ in Figure 8B.

The effect of changing the estimate of q can be seen from Figure 9, a plot of $\phi_{R}$ against $\phi_{N}$ that shows the curves that result when three values of $\mathrm{q}$ are used to calculate the equation

$$
\phi_{R}^{2.21}=\phi_{N}{ }^{\mathrm{q}}=R_{w} / R_{f}
$$

There is considerable scatter about the ideal line (that for which $q=2.1$ ), but in most cases the scatter corresponds to only a few percent in porosity.

The value of 2.1 used as the overall Archie's Law exponent is rather greater than that calculated from minicore samples by Karato (this volume). Using direct measurements of porosity and resistivity, Karato found a value for q of $1.67 \pm 0.27$, which suggests that the minicores display a greater degree of pore connectedness than the rock in the hole overall. Since a disproportionately large number of the minicores are from massive flows and pillow interiors (a fact underscored by the minicores' lower overall values of porosity), the greater degree of pore connectedness would be expected.

The value of $q$ is also rather larger than that calculated by Kirkpatrick (1979), who used resistivity and gamma density logs from Hole 396B.

In both Figures $8 \mathrm{~A}$ and $8 \mathrm{~B}$, porosity decreases with increasing depth, although there is some scatter, especially in $\phi_{N}$. The trend is better brought out in Figure 10, where 10-meter median values of porosity are plotted rather than individual points. The two curves in Figure 10 are remarkably similar in shape. The smaller degree of variation in $\phi_{R}$ is probably related to the resistivity tool's ability to penetrate the formation deeper than the neutron tool. Both curves show a general decrease in porosity from about $13 \%$ near the top of the basement ( $3748 \mathrm{~m}$ below the rig floor) to about $6 \% 250$ meters into the basement (3998 $\mathrm{m}$ below the rig floor) and a roughly constant value below that depth. The longspacing resistivity experiment (Von Herzen et al., this volume) resulted in a very similar porosity variation. The massive flow units stand out as having a porosity of about $5 \%$, regardless of depth in the section. The upper unit, which is near a below-rig depth of $\mathbf{3 8 0 0}$ meters, is, for this reason, the most striking, but the others stand out clearly as well.

Figure 11 further examines the Archie's Law exponent $\mathrm{q}$, which is calculated from neutron porosity as explained previously. Although the general level of $\mathrm{q}$ taken for all points remains more or less constant with increasing depth, this is not the case for points for which $\phi_{R}$ or $\phi_{N}$ calculates as being greater than $10 \%$. For these intervals of higher porosity, which exclude the massive flow units, q gradually increases with depth from about 2 at the top of the basement nearly to 3 toward the bottom of the hole. This change suggests that the degree of connectedness of the pores in the high porosity zones changes with depth, since $\mathrm{q}$ is related to connectedness, and neutron porosity, from which q is calculated, is not. The direction of the change would be from more connected pores at the top of the basement, with pores in the high porosity zones forming an interconnected network of cracks, to less connected pores deeper in the crust, where pores in the high porosity zones would be relatively isolated from one another.

This kind of change is consistent with the increasing degree of alteration with increasing depth in the hole, which itself is probably related to the increasing in situ temperatures (Honnorez et al., this volume). Alteration often results in the filling of the pores with minerals and the eventual isolation of the pores from one another, with a consequent change in the connectedness of the pores.

Figure 9, where $\phi_{R}$ is plotted against $\phi_{N}$, amplifies the evidence in Figure 11. The line of equal porosities in this plot corresponds to a value of q of 2.1, and the data for which $\phi_{N}$ is greater than $\phi_{R}$ correspond to values of $\mathrm{q}$ 


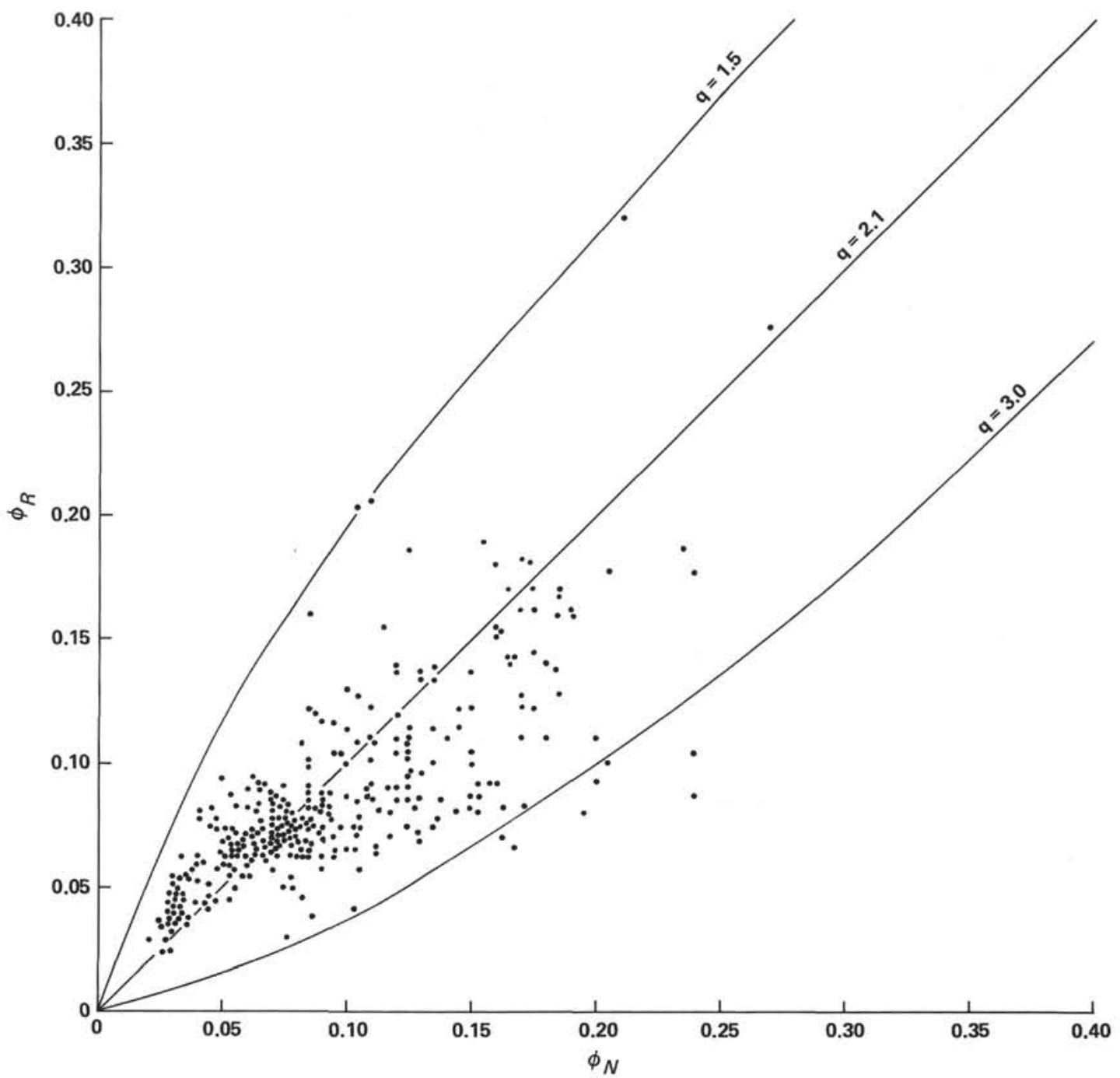

Figure 9. Porosity calculated from neutron log plotted against porosity calculated from resistivity log. Lines show values of Archie's Law exponent q. Hole 504B basement section.

greater than 2.1. Although the plot shows broad concordance between the values, as would be suggested by Figures 8 and 10, there are marked deviations from this. At low porosities, for example, $\phi_{R}$ is greater than $\phi_{N}$ on the average, suggesting that the pores are more connected in zones with a neutron porosity of less than $7 \%$, which are more common towards the bottom of the hole. It is in the region of such low porosities, however, that the neutron log is most dependent on such factors as hole diameter, which have not been accounted for here. The prevalence of values of q greater than 2.1 at high porosities shows clearly, as in Figure 11.

Comparison of the neutron and resistivity logs with the compensated gamma density log was hampered by the lack of a compensated density log for the bottom part of the hole. However, porosity was calculated from the gamma density data available, and the resulting values, $\phi_{D}$, are plotted against neutron porosity in Figure 12. Although there is good agreement in the values of porosity up to $15 \%$, at higher porosities there is pro- gressive deviation towards proportionately higher values of $\phi_{D}$. The values of $\phi_{D}$ reach levels greater than $50 \%$ if grain density is assumed to be $2.95 \mathrm{Mg} \mathrm{m}^{-3}$. The explanation for the deviation may be that the more porous zones have lower grain density, but the most likely reason for lower grain density would be hydration, which would give similarly high neutron porosities. Apparently the compensated density tool cannot be relied on to give realistic values of porosity, at least not in a basaltic formation, although it does identify the position of zones of high and low porosity in the hole.

The values of porosity derived here are significantly lower than those derived in other ways by Kirkpatrick (1979) and Salisbury et al. (1979). The reason for the difference is not clear. It may be related to the methods used to derive porosity or to the geological setting of the other sites. Sites 395 and 396 (Kirkpatrick, 1979) are in sediment ponds on rifted crust that is much more intensely faulted than the crust at Site 504. Site 417 (Salisbury et al., 1979) is in old Atlantic crust that is relatively rift- 


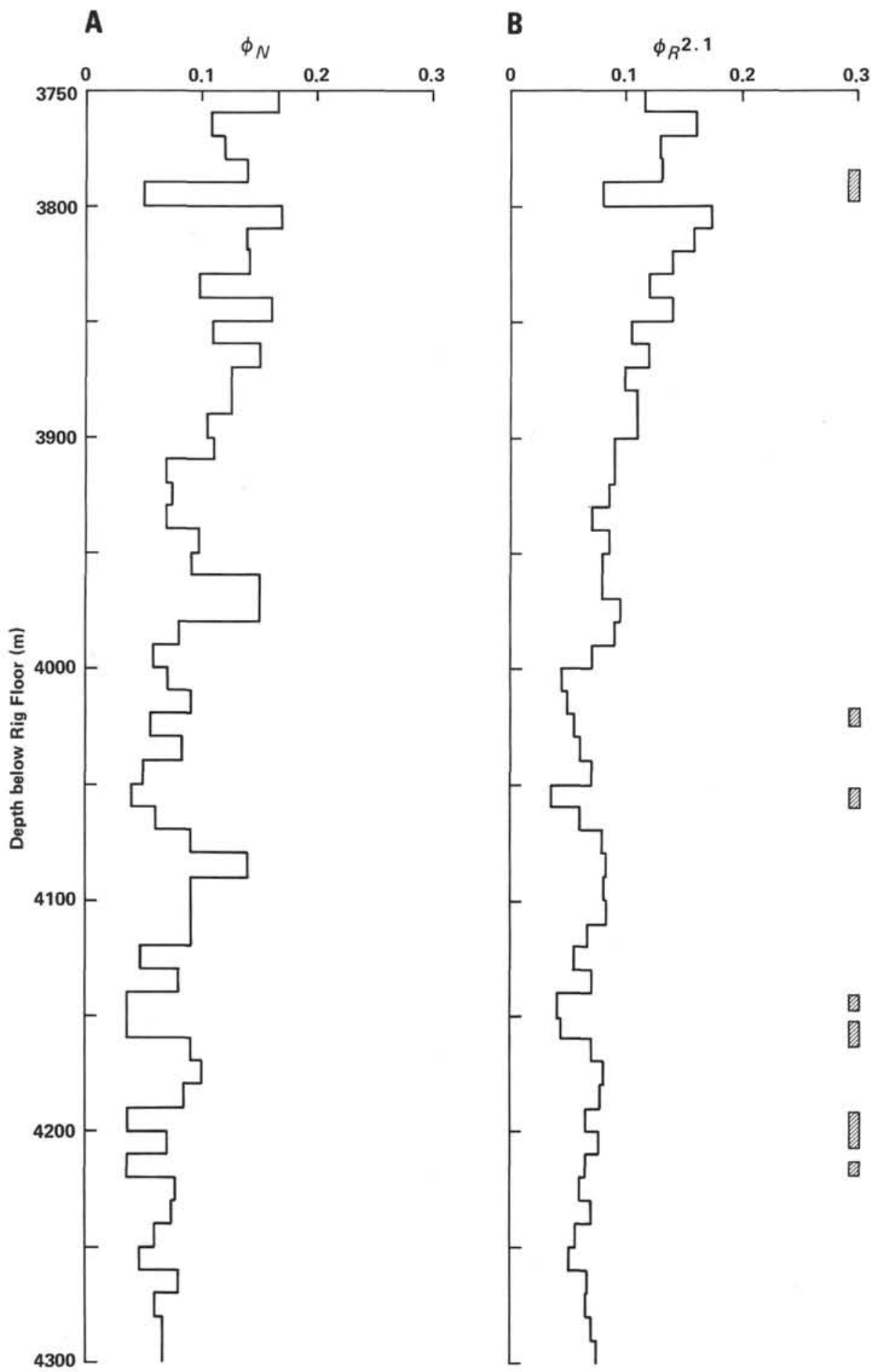

Figure 10. Porosity values for Hole 504B basement section calculated from (A) neutron log and (B) focussed resistivity. Values are 10-m median values derived from the points in Figure 8. Porosity is expressed as a fraction. Bars show massive flow units.

ed and has also had a long history of low temperature alteration. The significance of these differences will have to be evaluated after logging runs are made elsewhere.

At first sight, the sonic velocity log is very noisy and fails to provide much information. Some of the transit times measured correspond to a velocity lower than that in seawater or higher than that in peridotite (Fig. 5). A remeasurement of the bottom 50 meters of the hole pro- duced values that showed little similarity, on a 1-meter scale, to the values acquired when the entire section was measured. Both sets of values contain sudden transitions in transit time that suggest skipping. However, averaging the transit times over several meters smooths the record markedly, and a signal appears to emerge. Figure 13 is a plot in which 10-meter mean transit times have been converted to velocity, $V_{p}$. The figure also shows 


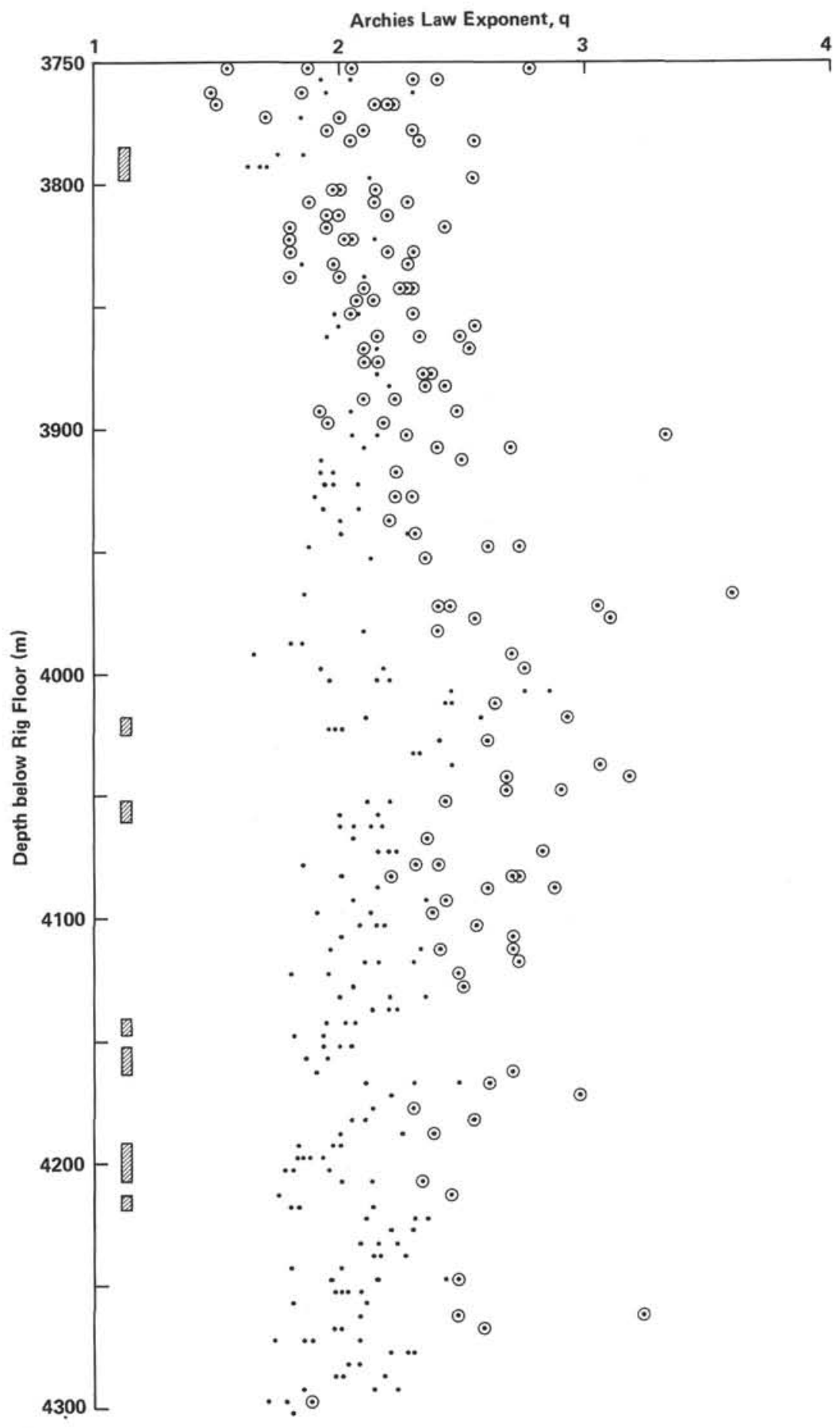

Figure 11. Archie's Law exponent for Hole 504B basement section calculated from neutron porosity and observed resistivity plotted against depth for the points shown in Figure 8 . Circles surround points for which either the neutron porosity or the resistivity-based porosity or both are greater than $10 \%$. Bars show massive flow units.

100-meter means. The plot shows a fairly steady increase in sonic velocity for the top $\mathbf{3 0 0}$ meters or so of the basement, with a rate of increase of about $5(\mathrm{~km} / \mathrm{s}) /$ $\mathrm{km}$ over that interval. Over the lower 300 meters of the basement, $V_{p}$ becomes much more uniform at about 4.6 $\mathrm{km} / \mathrm{s}$. Local high velocities correspond to massive flow units, which are also apparent in the resistivity and neutron plots in Figure 10. Indeed, there is a very close inverse relationship between sonic velocity and porosity. Figure 14 shows $V_{p}$ plotted against 10 -meter means of porosity calculated from resistivity, and the near linearity of the inverse relationship between these independent measurements is strong support for the idea that the smoothed velocity log is giving a clear signal. The mini- 


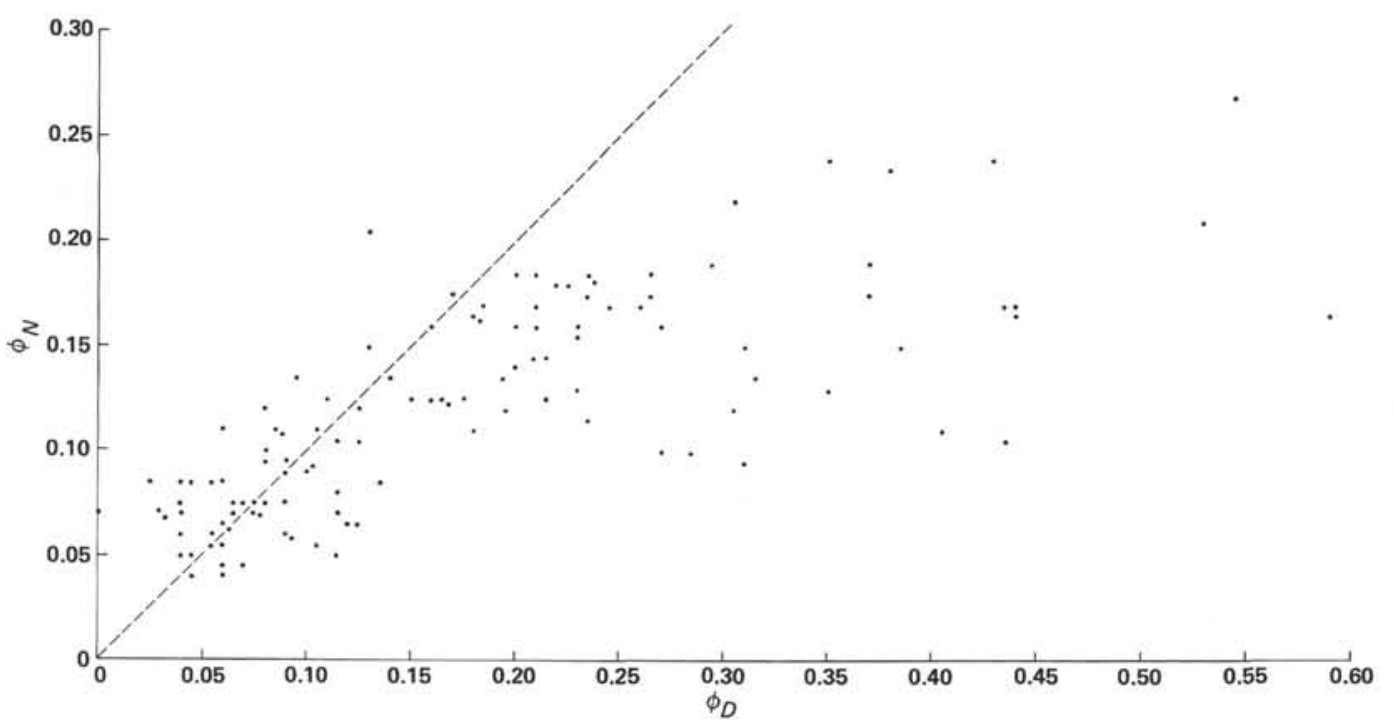

Figure 12. Porosity calculated from neutron log plotted against porosity calculated from compensated gamma density log. Assumed grain density: $2.95 \mathrm{Mg} \mathrm{m}^{-3}$. Hole 504B basement section.

core samples examined by Karato (this volume) produced lower values of sonic velocity for a given level of porosity, possibly because the minicore measurements of sonic velocity are less affected by cracks. Narrow cracks have little effect on porosity but markedly decrease sonic velocity. Another factor that may have contributed to the discrepancy is that the scale of measurement is different for the logging tool, which samples much larger volumes of material. This analysis thus indicates that despite small scale random variations, some of which must represent noise, the sonic log contains information at a larger scale that can be used to provide constraints on pore geometry and that can provide a way to relate marine seismic measurements (Stephen, this volume; and Langseth et al., this volume) to the rocks recovered.

\section{CONCLUSIONS}

The logs obtained at Sites 501, 504, and 505 proved to contain important information about the structure of the sections drilled. In the sediments of the high heat flow area (Holes 501 and 504A), the appearance in the logs of layers of chert separated by bands of limestone is very clear. An oscillation in the porosity-related logs on a scale of 1 to 3 meters in the basement at Holes 501, $504 \mathrm{~B}$, and 505B is related to the presence of pillow basalts or perhaps thin flows. Thick, massive flow units appear as sharply bounded zones of uniformly low porosity; they are scattered through the sections at random.

Over the long section of the deep hole at Hole 504B, neutron porosity was evaluated from standard calibration curves. Values of the Archie's Law exponent were calculated by using measured formation resistivity, seawater resistivity at the temperatures determined by logging, and values of neutron-derived porosity. The median value of the exponent calculated in this way is 2.1 , and resistivity porosities were calculated from observed resistivities using this exponent. Both measures of po- rosity show a decline from about $13 \%$ at the top of the basement to about $6 \% 250$ meters into the basement. Below that depth porosity is essentially constant at $6 \%$.

Although when all points are taken together the Archie's Law exponent is consistent through the depth of the hole, when only points corresponding to a porosity greater than $10 \%$ are considered, there is a systematic increase in the exponent from 2 to 3 from the top to the bottom of the basement section. This seems to represent a greater degree of pore connectedness at the top of the basement than at the bottom of the hole; thus, the porosity is more cracklike at the top and more porelike at the bottom. This in turn is probably related to the increased hydrothermal alteration caused by the higher temperatures in the deeper part of the section, with the consequent sealing of cracks by precipitating minerals.

The sonic $\log$ in Hole 504B was noisy on a small scale but appeared to give meaningful results when values averaged over intervals of 10 meters or more were judged against the independently measured resistivity log. The variations observed in the smoothed record of sonic velocity are related to the contrast between massive flows and pillow units. The log also shows a strong overall increase down the hole, with a gradient of about $5(\mathrm{~km} /$ $\mathrm{sec} / \mathrm{km}$ over the top 300 meters. In the lower part of the section this gradient declines substantially, and a mean sonic velocity of about $4.6 \mathrm{~km} / \mathrm{sec}$ is apparent. Compensated gamma density results were obtained for the upper part of the hole but gave unrealistically high values for the high porosity units, perhaps as a result of the small depth of penetration of the gamma radiation. The caliper log functioned well, but variation in hole size seemed to be related to neither the porosity nor the permeability of the basement. The message carried by the caliper log is probably significant but is not yet clear.

Despite the difficulties encountered, the operation as a whole was illuminating. The logging results, in particular those of the deep basement site, substantially supplement the logging results previously derived and give a 


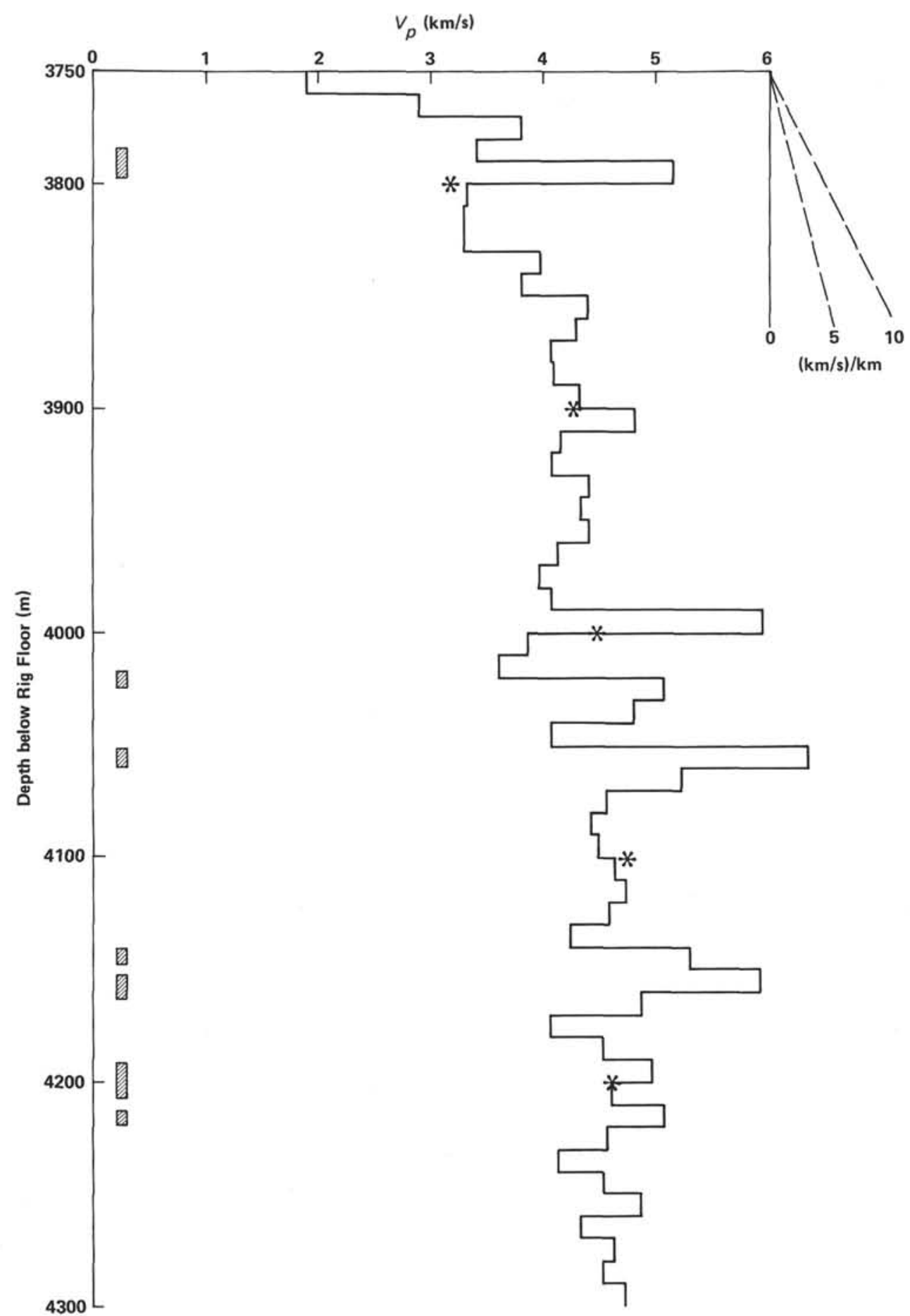

Figure 13. Sonic velocity plotted against depth below rig floor for the basement section of Hole 504B. Solid line gives velocity for $10-\mathrm{m}$ intervals calculated from mean transit times. Asterisks show $100-\mathrm{m}$ means calculated similarly. Bars show massive flow units.

much clearer picture of the nature of the ocean basement than any achieved before.

\section{ACKNOWLEDGMENTS}

We must fully acknowledge here the assistance and instruction of the many people who have helped us to understand some of the rudiments of log interpretation and who have discussed the meaning of these results at great length. In particular we thank Larry Axline,
Mark Langseth, Roy Wilkens, Matt Salisbury, Gene Boyce, and Roy Hyndman, who helped in their own ways to set a particular character on this paper. We are also greatly indebted to Christine Cochrane for drafting the figures so expertly. Tim Francis and Matt Salisbury reviewed the first draft of the paper and made many valuable suggestions.

\section{REFERENCES}

Archie, G. E., 1942. The electrical resistivity logs as an aid in determining reservoir characteristics. J. Petrol. Tech., 5:1-8. 
Formation evaluation data handbook, 1976. Fort Worth (GearhartOwen Industries, Inc.).

Francis, T. J. G., 1982. Effect of drill string movement on shape of the hole and on the cored rocks at Hole 459B. In Hussong, D. M., Uyeda, S., et al., Init. Repts. DSDP, 60: Washington (U.S. Govt. Printing Office), 835-840.

Kirkpatrick, R. J., 1979. The physical state of the oceanic crust: results of downhole geophysical logging in the Mid-Atlantic Ridge at $23^{\circ}$ N. J. Geophys. Res., 84:178-188.

Log interpretation charts. 1974. New York (Schlumberger Ltd.).

Log interpretation charts. 1979. New York (Schlumberger Ltd.).

Lonsdale, P., and Klitgord, K., 1978. Structure and tectonic history of the eastern Panama Basin. Geol. Soc. Am. Bull., 89:981-999.

Salisbury, M. H., Donnelly, T. W., and Francheteau, J., 1979. Geophysical logging in Deep Sea Drilling Project Hole 417D. In Donnelly, T., Francheteau, J., Bryan, W., Robinson, P., Flower, M., Salisbury, M., et al., Init. Repts. DSDP, 51, 52, 53, Pt. 1: Washington (U.S. Govt. Printing Office), 705-713.

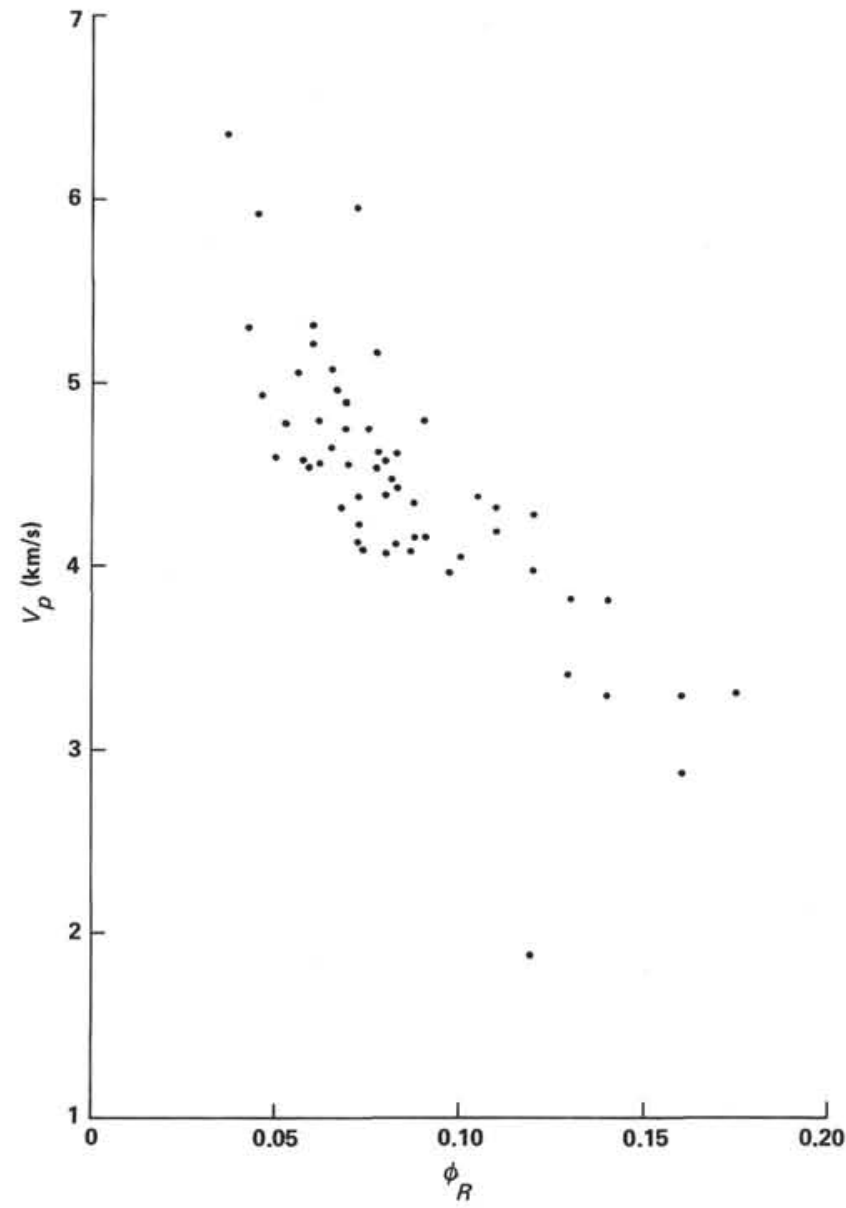

Figure 14. Sonic velocity plotted against porosity calculated from resistivity $\log$ using Archie's Law exponent of 2.1. Hole 504B basement section. 